\title{
ОЦІНКА ЕФЕКТИВНОСТІ МЕТОДІВ ДРЕСИРУВАННЯ ДЛЯ ПІДГОТОВКИ СЛУЖБОВИХ СОБАК
}

Степаненко Валентина Миколаївна

кандидат сільськогосподарських наук, доцент

Поліський національний університет ORCID: 0000-0002-3270-7348

E-mail: oksana_lavren@ukr.net

Лавринюк Оксана Олександрівна кандидат сільськогосподарських наук, доцент

Поліський національний університет ORCID: 0000-0003-3145-3689 E-mail: oksana_lavren@ukr.net

Борщенко Валерій Володимирович доктор сільськогосподарських наук, доцент

Поліський національний університет ORCID: 0000-0002-0710-5628

E-mail: kafgodivlya@ukr.net

Кривий Михайло Миколайович кандидат сільськогосподарських наук, доцент Поліський національний університет ORCID: 0000-0001-9428-0645 E-mail: kafgodivlya@ukr.net

Мамченко Віталій Юрійович кандидат сільськогосподарських наук, доцент Поліський національний університет ORCID: 0000-0002-7208-6363

E-mail: kafgodivlya@ukr.net

Хмельничий Леонтій Михайлович доктор сільськогосподарських наук, професор Сумський національний аграрний університет ORCID: 0000-0001-5175-1291 E-mail: khmelnychy@ukr.net

В даній статmі представлені дослідження по вивченню ефективності різних методів дресирування службових собак спеціального призначення. В кінології для дресирування собак застосовують такі основні методи: смакозаохочувальний (харчовий), механічний (фрізичний), контрастний та оперантний (ігровий). Дослідження проводились на базі Державної Установи «Житомирський навчальний центр підготовки поліцейських». Дослідженню підлягало 16 собак породи німецька вівчарка, 2 собаки породи спанієль, та 2 бельгійські вівчарки (малінуа), всього 20 голів. Відмінні результати показали собаки при застосуванні контрастного та оперантного методів дресирування. На підготовку собак для безвідмовного виконання навиків при контрастному методі було затрачено 30-35 днів, при оперантному методі - 25-30 днів. При харчовому методі тривалість підготовки собак склала в середньому 35-45 днів. Стосовно цього методу підготовки можна сказати, що у чистому вигляді він не ефективний. У собак проявляється небажаний зв'язок на корм, не бажання виконувати команди без «ласощів». Механічний метод без поєднання з харчовим практично не дав позитивних результатів. При спостеріганні швидкості вироблення умовних ресрлексів був прояв страху та подальша відмова від роботи. Для спеціального дресирування собак розшукової служби його не застосовують. Враховуючи переваги і недоліки кожного методу індивідуально підбирали найбільш ефективний для дресирування кожної тварини за спеціальним курсом дресирування. Після проходження спеціального курсу дресирування для розшукової служби пес повинен виконувати роботу із залишеними слідами (відпрацювання «по сліду»), проводити вибірку речей і проб із запахом, проводити вибірку конкретної людини з групи, обшукувати місцевість, знаходити по запаху стріляні гільзи, патрони, наркотичні та вибухонебезпечні речовин, зброю, набої, людські трупи та їх останки; мати вироблену активно-захисну реакцію до сторонніх та бути спроможним до захисту кінолога та затримання, конвоювання, і подальшої охорони затриманих злочинців. При розрахунку ефективності враховували такі показники як: кількість собак; середню живу масу 1 тварини; середню кількість затрачених та додаткових днів для утворення навику по кожному методу; вартість сухого корму «Club 4 раws» для активних собак; середньодобову даванку сухого корму. Результати досліджень показали, що найбільше кормів та коштів витрача- 
ється при застосуванні механічного та харчового методів дресирування. Затрати коштів на годівлю собак при використанні оперантного методу дресирування складають 675-810 грн. та при застосуванні контрастного методу підготовки - 891-1080 грн. Дані дослідження можуть бути корисними та використані в кінологічній роботі різних служб та підрозділів, у навчальному процесі при проведенні теоретичних та практичних занять з дресирування собак при підготовці кінологів.

Ключові слова: кінологія, спеціальне собаківництво, дресирування, методи дресирування.

DOI: https://doi.org/10.32845/bsnau.Ivst.2021.1.9

Людство багато століть тому оцінило природні особливості та якості собак: гострий нюх, гарний слух, хороший зір, швидкість руху, фізичну силу, спритність, і головне, податливість до виконання різних команд та завдань. Добре підготовлені службові собаки працюють рятувальниками, охоронцями, шукачами небезпечних речовин та зниклих людей, поводирями сліпих тощо. Але найголовніше це те, що собаки рятують багато життів, знаходячи приховані вибухові пристрої, заховані наркотики і зброю, шукають і знаходять злочинців $[2,3,8,12]$.

Актуальність теми досліджень полягає у тому, що напружена ситуація в нашій країні залишається складною, все частіше з'являються випадки прояву злочинності, загроза терактів тощо. Вивчення методів підготовки службових собак спеціального призначення для оперативного пошуку замаскованої вибухівки на тілі людини, у будівлях, транспорті, багажі, пошук наркотичних та інших небезпечних речовин на пунктах пропуску прикордонного контролю $є$ актуальним.

Спеціальність кінолога передбачає знання комплексу спеціальних кінологічних теоретичних знань і набуття практичних професійних навиків для підготовки та використанню службових собак у разі виникнення потреби держави, людства та конкретної людини $[3,8,10,12]$.

Фахівці та вчені у всьому світовому товаристві постійно відпрацюють та вдосконалюють різні заходи безпеки людей, застосовують новітні технології, знаходяться у постійному пошуку нових ефективних методів боротьби із злочинністю. Та не зважаючи на це, собачий нюх залишається чи неєдиним найефективнішим засобом при розшуковій роботі. Розрізнити та визначити за особливим запахом небезпечні речовини і предмети спеціально підготовлена службова собака може навіть у недоступних місцях при складних умовах роботи $[1,3,6]$.

Метод дресирування - це вплив на собаку певними подразниками (силою, ласощами, іграшками) для вироблення і утворення у неї необхідних спеціальних умовних рефлексів і доведення їх до складних навиків $[4,7,11]$.

У кінології для дресирування собак застосовують такі основні методи: смакозаохочувальний (харчовий), механічний (фізичний), контрастний та оперантний (ігровий).

Смакозаохочувальний (харчовий) метод, це досить поширений метод дресирування оснований на застосуванні харчових подразників (ласощів): сухого корму, шматочків м'яса тощо, для утворення у собак певних умовних рефлексів. Підготовленні цим методом собаки активно працюють, при цьому зміцнюється контакт собаки з кінологом. Суть методу полягає у тому, що собака по запаху шукає улюблений корм. За допомогою харчових подразників собаку наштовхують на виконання потрібних дій. Поступово, у процесі дресирування, корм замінюють на запахоносій розшуку (людини, вибухової речовини, наркотичної речовини тощо), а після знаходження або виявлення розшуканого запахоносія собаці дають ласощі, це як схвалення за правильно виконану команду. Найкраще цей метод застосовувати тоді, коли собака напівголодна або через 3-4 години після основної годівлі $[4,7,9,11,13]$.

Механічний (фізичний) метод дресирування полягає у застосуванні, у якості безумовного подразника, механічних подразників у вигляді фізичного, примусового впливу на тварину. За допомогою механічного примусу собаку спонукають до виконання певних команд, наприклад, таких як, сидіти, лежати, повзти, долати перешкоди, ходити поруч 3 дресирувальником та ін. У дресируванні собак на механічні (силові) подразники виробляється більшість загально дисциплінарних і спеціальних навиків. [9, 10].

Контрастний метод вважається головним у дресируванні, він об'єднує два попередні методи, всі позитивні моменти механічного і харчового (смакозаохочувального). Суть цього методу полягає у тому, що при дресируванні собак і утворенні певного умовного рефрлексу застосовується фізичний (механічний) вплив на собаку, а коли собака правильно виконує потрібну дію ӥй даються ласощі. Вважається, що даний метод дресирування досить ефективний, на ньому основується вироблення більшості умовних рефлексів у собак $[10,11,12]$.

Оперантний метод (ігровий). Цей метод оснований на бажанні та любові собаки грати з різними предметами (іграшками, м'ячиками, палками), носити «апорт». Особливе задоволення собака отримує під час гри з людиною яка кидає «апорт». Суть оперантного методу полягає у пошуку собакою улюбленої іграшки («апорту») за запахом. Дресирувальник кидає або ховає «апорт» у різних місцях, а собака його розшукує, знаходить, приносить дресирувальнику, або грається з ним. Цим методом можна відпрацьовувати багато команд як із загального так і спеціального курсу дресирування.

На початку занять, під час підготовки собак до пошуку вибухових та наркотичних речовин на місце «закладки» ховають «апорт», коли пес його знаходить за запахом, йому дають можливість пограти з «апортом». В процесі навчання поряд 3 іграшкою поміщають предмет із запахом шуканої речовини, привчаючи собаку до її пошуку. Згодом «апорт» не ховають разом із «закладкою», але обов'язково дають собаці в якості заохочення у разі виконання правильної дії на «закладку». Даний метод найбільш популярний в сучасній світовій кінології [1, 2, 7, 9, 10, 11].

Мета досліджень - вивчити та проаналізувати ефективність різних методів дресирування та підготовки собак для розшуковій служби.

Матеріали та методи досліджень. Дослідження проводились на базі Державної Установи «Житомирський навчальний центр підготовки поліцейських». Дослідженню підлягало 16 собак породи німецька вівчарка, 2 собаки породи спанієль та 2 бельгійські вівчарки (малінуа), всього 20 голів.

При виборі методу дресирування спочатку встановлювали тип вищої нервової діяльності собаки, характер і

Вісник Сумського національного аграрного університету 
ступінь прояву основних і переважаючих інстинктів (рефлексів) поведінки тварини. Оцінку кожного методу проводили під час загального курсу дресирування при навчанні собак основним обов'язковим командам - руху поруч з дресирувальником, витримці, командам «сидіти», «лежати» тощо.

Результати досліджень. Під час застосування різних методів дресирування собак було виявлено ряд недоліків кожного методу. При використанні смакозаохочувального методу спостерігалось часте відволікання собаки на улюблений запах, сторонні подразники, реагування тільки на їжу та відмова від роботи після годівлі. Це призводило до ненадійності виконання різних команд.

Недоліком механічного методу дресирування досить часто був прояв боязливості у собаки та подальша відмова тварини йти на контакт з людиною із за почуття больових відчуттів. Перенавантаження при фізичному впливі на собаку призводило до нервових зривів і гальмування роботи нервової системи.

При застосуванні контрастного методу також спостерігалися у собак небажані оборонні і харчові реакції, у де- яких тварин утворюватися умовні рефлекси агресії на силу та біль, жадність до корму.

Оперантний метод дресирування показав найкращі результати у дресируванні собак. Кількість недоліків при його застосуванні незначна.

Враховуючи переваги і недоліки кожного методу індивідуально підбирали найбільш ефективний для дресирування кожної тварини за спеціальним курсом дресирування. Після проходження спеціального курсу дресирування для розшукової служби пес повинен виконувати роботу із залишеними слідами (відпрацювання «по сліду»), проводити вибірку речей і проб із запахом, проводити вибірку конкретної людини з групи, обшукувати місцевість, знаходити по запаху стріляні гільзи, патрони, наркотичні та вибухонебезпечні речовин, зброю, набої, людські трупи та їх останки; мати вироблену активно-захисну реакцію до сторонніх та бути спроможним до захисту кінолога та затримання, конвоювання, і подальшої охорони затриманих злочинців.

Оцінка ефективності різних методів дресирування після тестування представлена у таблиці 1.

Таблиця 1

Результати оцінки методів дресирування собак для спеціальної служби

\begin{tabular}{|c|c|c|c|c|c|c|c|c|}
\hline \multirow{3}{*}{ Показники } & \multicolumn{8}{|c|}{ Методи дресирування } \\
\hline & \multicolumn{2}{|c|}{$\begin{array}{c}\text { Смакозаохоч. } \\
\text { (харчовий) }\end{array}$} & \multicolumn{2}{|c|}{ Механічний } & \multicolumn{2}{|c|}{ Контрастний } & \multicolumn{2}{|c|}{ Оперантний } \\
\hline & $1^{*}$ & $2^{*}$ & 1 & 2 & 1 & 2 & 1 & 2 \\
\hline Кількість затрачених (основних) днів для вироблення навику & 35 & $45 i>$ & 60 & - & 30 & 35 & 25 & 30 \\
\hline Кількість додаткових днів для дресирування собак & 10 & 15 & 20 & - & 3 & 5 & - & - \\
\hline Безвідмовне виконання всіх команд & - & - & - & & + & + & + & + \\
\hline Небажання виконувати команди & + & + & + & & - & - & - & - \\
\hline Пасивна поведінка під час занять & + & - & + & & - & - & - & - \\
\hline Утворення всіх складних стійких умовних рефлексів & - & - & - & & + & + & + & + \\
\hline Прояв небажаних зв'язків & + & + & + & & - & - & - & - \\
\hline Прояв агресії та зривів нервової системи & - & - & + & & - & - & - & - \\
\hline Вплив кліматичних умов під час дресирування & - & - & - & & - & - & - & - \\
\hline
\end{tabular}

$1^{*}$ - курс загальної підготовки:

$2^{*}$ - курс спеціальної підготовки.

Відмінні результати показали собаки при застосуванні контрастного та оперантного методів дресирування. На підготовку собак для безвідмовного виконання навиків при контрастному методі було затрачено 30-35 днів, при оперантному методі - 25-30 днів.

При харчовому методі тривалість підготовки собак склала в середньому 35-45 днів. Стосовно цього методу підготовки можна сказати, що у чистому вигляді він не ефективний. У собак проявляється небажаний зв'язок на корм, не бажання виконувати команди без «ласощів».

Механічний метод без поєднання з харчовим практично не дав позитивних результатів. При спостеріганні швидкості вироблення умовних рефлексів був прояв страху та подальша відмова від роботи. Для спеціального дресирування собак розшукової служби його не застосовують.

Після проходження спеціального курсу дресирування для розшукової служби пес повинен виконувати роботу із залишеними слідами (відпрацювання «по сліду»), проводити вибірку речей і проб із запахом, проводити вибірку конкретної людини з групи, обшукувати місцевість, знаходити по запаху стріляні гільзи, патрони, наркотичні речовин, вибухонебезпечні речовин, зброю, набої, людські трупи та їх останки) мати вироблену активно-захисну реакцію до сторонніх та бути спроможним до захисту кінолога та затримання, конвоювання, і подальшої охорони затриманих злочинців.

Зважаючи на те, що економічну ефективність досліджень з оцінки методів дресирування собак для спеціальної служби у кінології не встановлюють, так як методика її визначення не прописана у Інструкції з організації діяльності кінологічних підрозділів ДСНС [5].

Враховуючи кількість затраченого часу (днів) для вироблення навику у собак при різних методах дресирування, витрату та вартість кормів для їх годівлі, нами були проведені розрахунки представлені у таблиці 2. 
Таблиця 2

Ефективність методів дресирування службових собак

\begin{tabular}{|c|c|c|c|c|c|c|c|c|}
\hline \multirow{3}{*}{ Показники } & \multicolumn{8}{|c|}{ Методи дресирування } \\
\hline & \multicolumn{2}{|c|}{ Харчовий } & \multicolumn{2}{|c|}{ Механічний } & \multicolumn{2}{|c|}{ Контрастний } & \multicolumn{2}{|c|}{ Оперантний } \\
\hline & $1^{*}$ & $2^{*}$ & 1 & 2 & 1 & 2 & 1 & 2 \\
\hline Всього собак породи німецька вівчарка, гол. & 16 & 16 & 16 & 16 & 16 & 16 & 16 & 16 \\
\hline Кількість затрачених (основних) днів для вироблення навику & 35 & 45 & 60 & - & 30 & 35 & 25 & 30 \\
\hline Кількість додаткових днів для дресирування собак & 10 & 15 & 20 & - & 3 & 5 & - & - \\
\hline Вартість сухого корму, грн./кг & 54 & 54 & 54 & - & 54 & 54 & 54 & 54 \\
\hline Добова даванка, г & 500 & 500 & 500 & - & 500 & 500 & 500 & 500 \\
\hline Вартість корму на голову на добу, грн. & 27 & 27 & 27 & - & 27 & 27 & 27 & 27 \\
\hline Всього витрачено корму на основний період підготовки собак, кг & 17,5 & 22,5 & 30 & - & 15 & 17,5 & 12,5 & 15 \\
\hline $\begin{array}{l}\text { Затрати коштів на годівлю собак з урахуванням додаткових днів на } \\
\text { дресирування, грн./гол. }\end{array}$ & 1215 & 1620 & 2160 & - & 891 & 1080 & 675 & 810 \\
\hline Затрати на все поголів'я собак, грн. & 19440 & 25920 & 34560 & - & 14256 & 17280 & 10800 & 12960 \\
\hline
\end{tabular}

Так як у центрі утримуються собаки трьох різних порід і витрати корму на їх утримання різні, нами були проведені розрахунки ефеективності дресирування тільки для німецьких вівчарок середньою живою масою 30 кг. Кількість собак породи німецька вівчарка - 16 голів.

Для годівлі собак кінологічного центру використовують сухі концентровані повнораціонні корми. Вони не потребують додаткового приготування, їх зручно роздавати та згодовувати тваринам. Додаткові витрати на утримання собак, їх догляд, на інвентар та ветеринарне обслуговування не враховувалися.

При розрахунку ефрективності враховували такі показники як: кількість собак (16 голів); середню живу масу 1 тварини (30 кг); середню кількість затрачених та додаткових днів для утворення навику по кожному методу; ціну сухого корму «Club 4 paws» для активних собак станом на 01.11.20 р. (54 грн./кг); середньодобову даванку сухого корму - 500 г на голову.

В результати проведених розрахунків показали, що найбільші затрати кормів та коштів при застосуванні механічного та харчового методів дресирування. Найефективнішими методами дресирування є оперантний та контрастний. Затрати коштів на годівлю собак при використанні цих методів дресирування складають 675-810 грн. (оперантний) та 891-1080 грн. (контрастний) з урахуванням основного та додаткового періоду підготовки.

Висновки. У Державній Установі «Житомирський навчальний центр підготовки поліцейських» створені всі необхідні умови для утримання службових собак, проходження ними загального і спеціального курсу дресирування, для проведення тестування на придатність до виконання конкретного виду служби.

При оцінці різних методів дресирування найкращі результати показали собаки при застосуванні контрастного та оперантного методів. На підготовку собак для безвідмовного виконання навиків при контрастному методі було затрачено 30-35 днів, при оперантному методі - 25-30 днів.

Найбільші затрати кормів та коштів відбуваються при застосуванні механічного та харчового методів дресирування. Затрати коштів на годівлю собак при використанні оперантного методу дресирування складають 675-810 грн. та при застосуванні контрастного методу підготовки - 891-1080 грн.

Для дресирування та підготовки службових собак у кінологічних центрах необхідно застосовувати найефективніші методи дресирування, а саме оперантний та контрастний; звести до мінімуму застосування механічного методу без смакового заохочення, як самого травматичного для нервової системи тварин.

\section{Список використаної літератури:}

1. Була Л. В. Оцінка службових собак, які дресируються по пошуку наркотичних засобів та зброї : дис. ... канд. с.-г. наук : спец. 06.02.01. с. Чубинське Київської області, 2009. 171 с.

2. Виноград О. В. Основи службової кінологї. Хмельницький : Меркьюріті-Поділля, 2011. 192 с.

3. Гармаш В. В. Місце кінологічних підрозділів у структурі національної поліції України та в системі Міністерства внутрішніх справ. Право і безпека, ХНУBC, 2019. № 3 (74) C. 24-29. URL: http://old.pb.univd.edu.ua/?action=publications\&pub name=pravo i bezpeka\&mid=8 (дата звернення: 20.12.2020).

4. Зубко В. Н. Основы служебного собаководства. Москва : ДОСААФ, 1975. 400с.

5. Інструкція 3 організації діяльності кінологічних підрозділів ДCHC. URL : http //search.ligazakon.ua//_doc2.nsf/link1/RE32348.html (дата звернення: 23.12.2020).

6. Кинология: учебное пособие для вузов / Блохин Г. И. и др.. Санкт-Петербург: Лань, 2017. 376 с.

7. Методы и приемы дрессировки служебных собак. Всеукраинское кинологическое объединение. URL: Http://uka.org.ua/dressirovka-sobak/25-dressirovka-sobak/320-metody-i-priemy-dressirovki-sluzhebnykh-sobak (дата звернення: 20.12.2020).

8. Мордюшенко С. М. Специфіка та психологічні особливості діяльності кінологічної служби. Вісник Національного університету оборони України: зб. наук. праць. 2013. Вип. 1 (32). С. 245-252.

9. Орлов А. И. Методика дрессировки служебных собак. Москва : ДОСААФ, 1978. С. 55-77.

10. Полищук Ф. К, Трофименко О. Л. Основы кинологии. Теоретический и практический аспекты дрессировки. Киев- 
Ирпень : Перун, 2003. 200 с.

11. Черкашин А. В., Коваленко Б. П. Методи дресирування собак службових порід. Розведення тварин - актуальні проблеми та шляхи їх вирішення: зб. наук.-реф. праць. студентів та магістрів. Харківська державна зооветеринарна академія, 2009. Вип. 3. С. 64-65.

12. Шутенко О. О., Красьоха Я. В. Основи службової кінології: Навчальний посібник для підготовки фахівцівкінологів. Київ: ДП «Друкарня МВС України», 2008. 312 с.

13. Языков В. В. Теория и техника дрессировки служебных собак. Москва : Воениздат, 1932, 281 с.

\section{References:}

1. Bula, L. V., 2009. Estimation of service dogs which were trained on search of narcotic means and the weapon. Ph. D. thesis of Agricultural sciences. Institute of Animals Breeding and Genetics NAAS, Chubynske.

2. Vynohrad, O. V., 2011. Osnovy sluzhbovoi kinolohii [Service Cynology Fundamentals]. Khmelnytskyi : Merkiuriti-Podillia.

3. Harmash, V. V., 2019. The place of canine units in the structure of the National Police of Ukraine and in the system of the Ministry of Internal Affairs. Pravo $i$ bezpeka, KhNUVS. Avaible at : http://old.pb.univd.edu.ua/?action=publications\&pub_name=pravo_i bezpeka\&mid=8 [Accessed 20 January 2020].

4. Zubko, V. N., 1975. Osnovy sluzhebnogo sobakovodstva [Service Dog Breeding Basics]. Moskva : DOSAAF.

5. Instructions for organizing the activities of canine units of the SES. Avaible at : http : //search.ligazakon.ua/l_doc2.nsf/link1/RE32348.html [Accessed 20 January 2020].

6. Blokhin, G. I. [et al]. 2017. Kinologiya: uchebnoe posobie dlya vuzov [Cynology: a textbook for universities]. SanktPeterburg: Lan'.

7. Methods and techniques for training service dogs. All-Ukrainian Cynological Association. Avaible at : Http://uka.org.ua/dressirovka-sobak/25-dressirovka-sobak/320-metody-i-priemy-dressirovki-sluzhebnykh-sobak (Accessed 20 January 2020).

8. Mordiushenko, S. M., 2013. Spetsyfika ta psykholohichni osoblyvosti diialnosti kinolohichnoi sluzhby [Specifics and psychological features of the dog service]. Visnyk Natsionalnoho universytetu oborony Ukrainy: zb. nauk. prats, issue 1(32), pp. 245252.

9. Orlov, A. I., 1978. Metodika dressirovki sluzhebnykh sobak [Service dog training method]. Moskva : DOSAAF.

10. Polishchuk, F. K. and Trofimenko, O. L., 2003. Osnovy kinologii. Teoreticheskiy i prakticheskiy aspekty dressirovki [Cynology basics. Theoretical and practical aspects of training]. Kiev-Irpen' : Perun.

11. Cherkashyn, A. V. and Kovalenko, B. P., 2009. Metody dresyruvannia sobak sluzhbovykh pored [Methods of training dogs of service breeds]. Rozvedennia tvaryn - aktualni problemy ta shliakhy yikh vyrishennia: zb. nauk.-ref. prats. Kharkivska derzhavna zooveterynarna akademiia, issue 3, pp. 64-65.

12. Shutenko, O. O. and Krasokha, Ya. V., 2008. Osnovy sluzhbovoi kinolohii: Navchalnyi posibnyk dlia pidhotovky fakhivtsiv-kinolohiv [Fundamentals of service cynology: A textbook for the training of cynologists]. Kyiv: DP «Drukarnia MVS Ukrainy».

13. Yazykov, V. V., 1932. Teoriya i tekhnika dressirovki sluzhebnykh sobak [Theory and technique of training service dogs]. Moskva : Voenizdat.

Stepanenko Valentyna Mykolaivna, Ph.D. of Agricultural Sciences, docent

Lavryniuk Oksana Oleksandrivna, Ph.D. of Agricultural Sciences, docent

Borshchenko Valerii Volodymyrovych, Doctor of Agricultural Sciences, docent

Kryvyi Mykhailo Mykolaiovych, Ph.D. of Agricultural Sciences, docent

Mamchenko Vitalii Yuriiovych, Ph.D. of Agricultural Sciences, docent

Polissya National University (Zhytomyr, Ukraine)

Khmelnychyi Leontii Mykhailovych, Doctor of Agricultural Sciences, Professor

Sumy National Agrarian University (Sumy, Ukraine)

Evaluation of efficiency of training methods for training service dogs

This article presents research to study the effectiveness of various methods of training service dogs for special purposes. In cynology, the following basic methods are used for dog training: taste-promoting (food), mechanical (physical), contrast and operant (game). The research was conducted on the basis of the State Institution "Zhytomyr Police Training Center". The study involved 16 dogs of the German Shepherd breed, 2 dogs of the Spaniel breed, and 2 Belgian Shepherds (Malinois), a total of 20 heads. Dogs showed excellent results when using contrast and operant training methods. 30-35 days were spent on training dogs for trouble-free performance of skills with the contrast method, and 25-30 days with the operant method. With the food method, the duration of training dogs was an average of 35-45 days. Regarding this method of preparation, we can say that in its pure form it is not effective. Dogs show an undesirable connection to food, unwillingness to carry out commands without "treats". The mechanical method without a combination with food practically did not give positive results. When observing the rate of production of conditioned reflexes, there was a manifestation of fear and subsequent refusal to work. It is not used for special training of dogs of search service. Given the advantages and disadvantages of each method individually selected the most effective for training each animal on a special training course. After undergoing a special training course for the search service, the dog must perform work with the traces left (working "on the trail"), sampling things and samples with the smell, sampling a specific person from the group, search the area, find the smell of bullet casings, ammunition, drugs and explosives, weapons, ammunition, human corpses and their remains; to have developed an active-protective reaction to outsiders and to be able to protect the cynologist and the detention, escort, and 
further protection of detained criminals. When calculating the effectiveness of such indicators as: the number of dogs; the average live weight of 1 animal; the average number of days spent and additional to develop a skill for each method; the cost of dry food "Club 4 paws" for active dogs; average daily intake of dry food. The results of research have shown that most feed and funds are spent on the use of mechanical and food training methods. The cost of feeding dogs when using the operant method of training is 675-810 UAH. and when using the contrast method of preparation - UAH 891-1080. These studies can be useful and used in the canine work of various services and departments, in the educational process in conducting theoretical and practical classes on dog training in the training of cynologists.

Key words: cynology, special dog breeding, training, training methods.

Дата надходження до редакції: 02.02.2021 p. 